\title{
Potential profit gains from improving pasture productivity on New Zealand South Island high-country farms
}

\author{
Charles A. MORRISON, Victoria C.F. WESTBROOKE* and Jim L. MOIR \\ Lincoln University, PO Box 85084, Lincoln 7647, Canterbury, New Zealand
}

*Corresponding author: victoria.westbrooke@lincoln.ac.nz

\begin{abstract}
Soil acidity combined with low levels of key nutrients on New Zealand hill-country farms are limiting factors for legume establishment/growth. However, legumes are a critical component of these farms as they provide nitrogen and high-quality feed. A farm-systems model was developed to estimate the impact of targeted fertiliser and lime application, combined with sowing clover, on whole-farm productivity and profitability. A base model was developed that incorporated 17 years' worth of Beef + Lamb NZ survey data for Class 1: South Island Farms. This base model was then used investigate two lime-application/oversowing models where part of the modelled high-country farm was targeted for improvement: (1) Conservative, i.e. 0.6\% farm area; and (2) Aggressive, i.e. 2.8\% farm area. Three scenarios to utilise the additional pasture grown were then investigated for each model by: (a) increasing ewe numbers; (b) increasing ewe performance (lambing percentage); and (c) increasing liveweight gain of stock. Scenario 2a, generated the highest profitability level (Earnings before Interest Tax and Rent, EBITR $\$ 58,870$ ) above the base model but became less financially attractive when the two years required to build the maternal ewe flock were factored in. Scenarios $2 \mathrm{c}$ and $1 \mathrm{~b}$ generated increases in profitability (EBITR) between $\$ 33,310$ and $\$ 41,290$ above the base model. Variation in product prices, production levels and time to develop the final farm-management system would also influence the productivity and profitability of the scenarios. Environmental aspects, infrastructure and staff availability would affect the suitability of the development for individual farming businesses.
\end{abstract}

Keywords: high country, lime, farm profit, Farmax, farm systems

\section{Introduction}

Legumes are a critical component of high country and other farming systems as they provide nitrogen via N-fixation (Haynes \& Williams 1993) and also highquality feed to drive animal performance (Hoffman et al. 2007). However, soil acidity combined with low levels of plant-available phosphorus and sulphur are key limiting factors for legume establishment and growth. This is a large-scale issue as approximately
500,000 ha of farmed New Zealand South Island highcountry soils have low $\mathrm{pH}$ and possibly high aluminium concentrations (Moir \& Moot 2010). Consequently, high-country farms may struggle to be sustainable businesses in the long term without increasing soil $\mathrm{pH}$ by topdressing with fertiliser and lime in order to improve legume productivity (Moir \& Moot 2014).

Topdressing with lime and fertiliser is carried out infrequently in the high country due to the high cost of application (Moir \& Moot 2010). Farms can be located some distance from lime quarries increasing transportation costs, and steeper parts of the farms require more expensive aerial application of fertiliser and lime. One approach could be to focus on improving the productivity of lower and mid-elevation areas of the farms (Maxwell et al. 2010) via a development programme with lime, fertiliser and over sowing.

Maximum returns from land development may not be achieved unless fine tuning of the existing farm management and economic factors are considered first (Frengley \& Anderson 1989). A key consideration with any farmland development, assuming the productivity capacity is increased, is how the farming system can be adjusted to utilise any additional pasture growth Often with large-scale development there is an increase in the stocking rate and or a change in the stock policy, for example including more finishing in the system (Gaukrodger 2015).

A farm-systems model was developed using Farmax software (Farmax n.d.) to estimate the impact of targeted land development on whole-farm productivity and profitability. The model developed was used to investigate two lime-application/oversowing models where part of a simulated high-country farm was targeted for improvement: (1) Conservative, i.e. $0.6 \%$ farm area; and (2) Aggressive, i.e. 2.8\% farm area. The profitability of these models was compared using EBITR, as the measure is independent of business ownership and funding (Shadbolt \& Gardner 2005). Three scenarios to utilise the additional pasture grown were then investigated by: (a) increasing ewe numbers; (b) increasing ewe performance (lambing percentage); and (c) increasing liveweight gain of stock. This paper reports the effects of applying these models and scenarios on whole-farm productivity and profitability. 


\section{Materials and Methods}

A farm model was constructed from Beef + Lamb NZ survey data for Class 1: South Island High Country farms (Beef + Lamb New Zealand 2019). Mean survey data for the seventeen years (2000-01 to 2016-17) were ranked by EBITR per stock unit. Data from quartile two was selected to provide the physical and financial data for the model. This quartile was selected as there was the potential to improve EBITR and farms in this quartile applied less lime and fertiliser per hectare, on average than farms in the other quartiles.

The farm simulation was developed using farmsystems modelling software (Farmax Sheep, Beef \& Deer (7.2.2.04)) (Farmax n.d.). Data on farm location, topography, pasture type and growth rate, liveweights, mating and calving/lambing dates were not available from the survey. Assumptions were made for these factors based on the environmental conditions farms near Omarama, Mackenzie Basin, South Canterbury, would experience with an annual rainfall of $500 \mathrm{~mm}$. The base farm model was 12,500 ha, and consisted of developed (2\%), underdeveloped (9\%), medium slope hill $(24 \%)$ and steep slope hill $(65 \%)$ country. Overall, the simulated farm produced $6 \mathrm{tDM} / \mathrm{ha}$ of utilised pasture. The maternal merino flock (4167 head) was mated to a merino ram with a lambing percentage of $89 \%$. All hoggets (1177 head) were kept on farm, with a replacement rate of $20 \%$ mixed age ewes. Shorn wool sold was $4.90 \mathrm{~kg}$ per ewe and $2.74 \mathrm{~kg}$ per hogget. The beef enterprise consisted of Hereford cattle with a calving percentage of $81 \%$. The base model had a stocking rate of 0.5 stock units (SU)/ha and a ratio of sheep to beef of 75:25.

\section{Land improvement model and scenario development}

The base model was adapted to generate: (1) a Conservative; and (2) an Aggressive lime-application/ oversowing model. With the Conservative model, $\$ 21,000$ was allocated to capital lime, application and reseeding costs to develop 70 ha, or $0.6 \%$ of the modelled farm. With the Aggressive model, 345 ha, or $2.8 \%$ of the farm was improved (Table 1 ).

An increase of 0.2 units of soil $\mathrm{pH}$ per tonne of lime applied was predicted and over-sowing with Trifolium subterraneum (subterranean clover; which could not previously persist and grow without liming; Moir et al. 2016) was used to estimate the additional feed grown. Both lime-application/oversowing models were then used to test three scenarios to utilise the additional feed grown: (a) increasing ewe numbers; (b) increasing ewe performance (lambing percentage); and (c) increasing liveweight gain of stock (Figure 1). These scenarios were analysed in both models 1 and 2 to find the most productive and profitable development option.

Scenario (a) was achieved by scaling the ewe flock, and the associated reconciliation, to consume the additional feed grown. For the Conservative model (1), sheep numbers were scaled up by $4 \%$ and for the Aggressive model (2), sheep numbers were scaled up by $14 \%$. The initial increase in ewe lambs retained to build the maternal ewe flock was modelled over a twoyear time period using the short-term mode in Farmax (Farmax n.d.).

Increasing sheep and cattle performance was achieved though improving either lambing percentage by $9 \%$ (Scenario b) or liveweight gain of sheep and cattle (Scenario c) post land development. Increasing lambing percentage (Scenario b) was not accompanied by an increase in ewe liveweight. The amount of daily dry matter consumed was as closely aligned as biologically feasible across the scenarios generated.

\section{Financial analysis}

Product prices were from the default South Island highcountry values already included in the Farmax model system (Farmax n.d.). Livestock prices were based on the 2019 South Island sheep and beef schedules. The farm working expenses, wages, weed and pest, animal health, repairs and maintenance, administration, cartage rates, depreciation and electricity (see Appendix) were based on the Beef + Lamb NZ survey data for Class 1: South Island High Country farms (Beef + Lamb NZ 2019). The remaining expenses were based on the default South Island high-country values already included in the Farmax model system (Farmax n.d.).

Scenarios (b) and (c) were modelled in the final farm system with the sheep numbers at the desired level using the long-term mode in Farmax (Farmax n.d.). In Scenario (a), it took two years to build the maternal ewe flock to the desired level. The financial results presented for this Scenario were from the third year, which is a future value that needs to be discounted back two years to a present value in order to be comparable with the financial results from the other scenarios, which took one year to achieve. A discount rate of $7 \%$ (based on a $5 \%$ bank mortgage rate and a $2 \%$ personal factor) was used to calculate the present value for this analysis. Expenses were calculated primarily on a 'per stock unit' basis, where a stock unit was considered to be $550 \mathrm{~kg}$ DM eaten.

\section{Results}

Animal intake was closely aligned across all scenarios to ensure they were comparable. The biological feasibility of each scenario was also assessed. Simulation of Scenario 2b (Aggressive + increased lambing percentage) generated a lambing percentage that was considered too high for the farming conditions and biologically infeasible. Thus, the results for this Scenario were not considered in the remainder of the study. 
Table 1 Development costs for the Conservative and Aggressive lime-application/oversowing models.

\begin{tabular}{lccc}
\hline & \multicolumn{2}{c}{ Model } \\
\cline { 2 - 4 } & Unit cost (\$/ha) & 1. Conservative (\$ for 70 ha) & 2. Aggressive (\$ for 345 ha) \\
\hline Spraying cost & 40.00 & 2,800 & 13,800 \\
Seed (subterranean clover 10 kg/ha) & 80.00 & 5,600 & 27,600 \\
Lime (2.5 t/ha) & 75.00 & 5,250 & 25,875 \\
Superphosphate (250 kg/ha) & 86.00 & 6,020 & 29,670 \\
Spreading & 19.00 & 1,330 & 6,555 \\
Total (\$) & & $\mathbf{2 1 , 0 0 0}$ & $\mathbf{1 0 3 , 5 0 0}$ \\
\hline
\end{tabular}

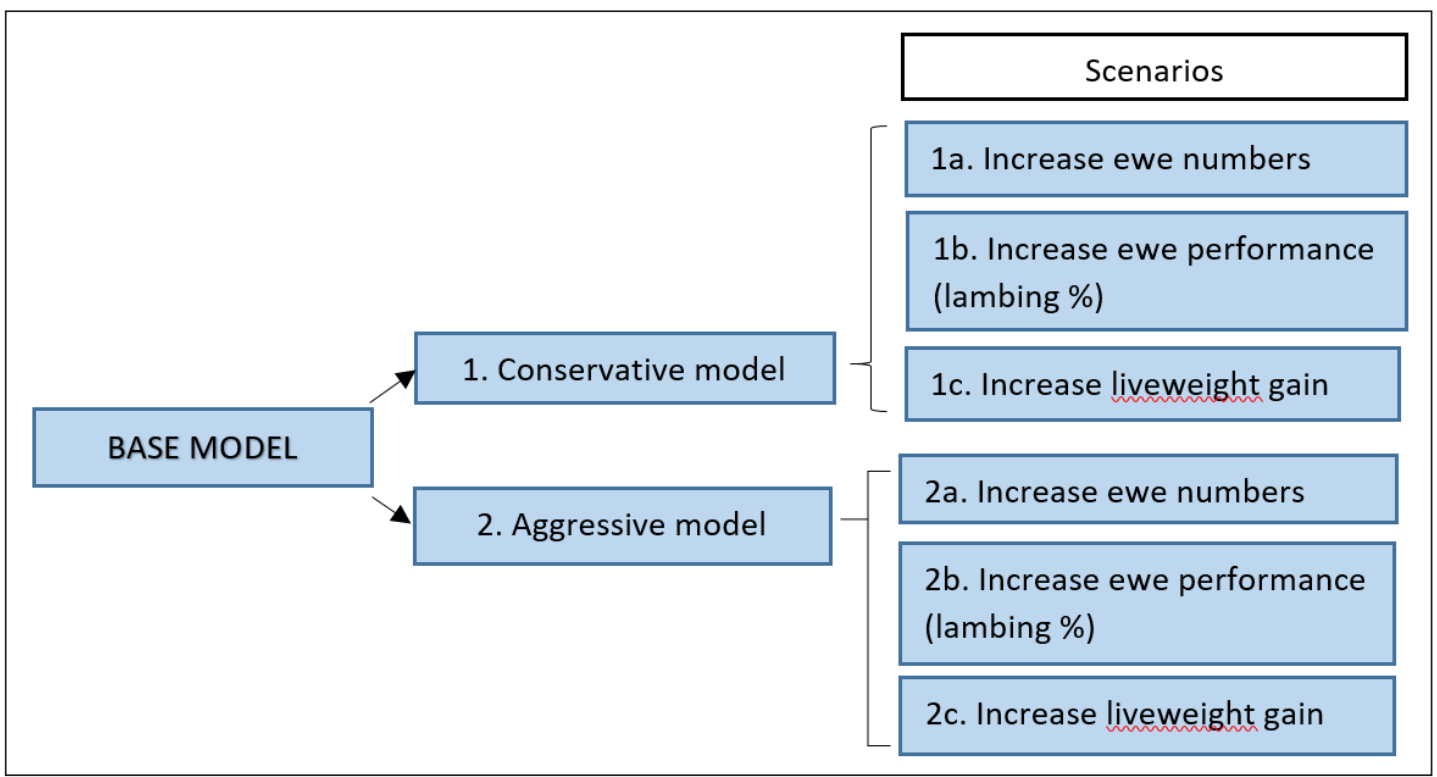

Figure 1 Flow diagram showing the lime-application/oversowing models used and the utilisation of the additional pasture grown scenarios tested.

\section{Pasture consumption and stocking rate}

Application of either Scenario $2 \mathrm{a}$ or $2 \mathrm{c}$ resulted in a slight increase in stocking rate $(0.6 \mathrm{SU} / \mathrm{ha})$ compared with the base farm model $(0.5 \mathrm{SU} / \mathrm{ha})$ or the other Scenarios tested (Table 2). Implementation of all scenarios led to an increase in pasture eaten compared with the base model (Table 2). The ratio of sheep to beef remained constant at 75:25 for Scenarios $1 \mathrm{a}-\mathrm{c}$ and $2 \mathrm{a}$ but Scenario $2 \mathrm{c}$ resulted in more sheep, with a ratio of 77:23.

\section{Livestock sales}

Scenarios 1a and 2a both led to increased stock sales in Year 3 compared to the base farm model, although weights at which stock were sold were similar across all models (Table 3). Ewe sales to the works were 4\% and $14 \%$ higher for Scenario 1a and 2a respectively compared to the base system. Ewe hogget sales were
$4 \%$ and $13 \%$ higher and mixed hoggets $4 \%$ and $14 \%$ higher for Scenario 1a and 2a respectively compared to the base system.

Scenario $1 \mathrm{~b}$ led to $16 \%$ more mixed hoggets sold with similar livestock sale weights than in the base farm model.

Scenario $1 \mathrm{c}$ resulted in the sale of mixed hoggets that were $12 \%$ heavier than the base model. In Scenario $2 \mathrm{c}$, just over half $(55 \%)$ the mixed hoggets were sold as finished, the only scenario to do so. In addition, the hoggets sold store from the aggressive model were $8 \%$ heavier than those sold store from the base model. The number of ewes and ewe hoggets sold from the base, conservative and aggressive models were the same, however ewe hoggets sold from the conservative and aggressive models were 16 and $35 \%$, respectively heavier than those sold from the base model. 
Table 2 Comparison of total pasture eaten, stocking rate and feed conversion efficiency for various lime-application/oversowing models and pasture utilisation scenarios.

\begin{tabular}{lccc}
\hline Model + Scenario & $\begin{array}{c}\text { Stocking rate } \\
\text { (SU/ha) }\end{array}$ & $\begin{array}{c}\text { Total pasture eaten } \\
\text { (kgDM/ha) }\end{array}$ & $\begin{array}{c}\text { Feed conversion efficiency } \\
\text { (kgDM/kg product) }\end{array}$ \\
\hline Base model & 0.5 & 290 & 35.4 \\
\hline 1. Conservative model & & 299 & 35.4 \\
1a. Increase ewe numbers & 0.5 & 298 & 34.4 \\
1b. Increase ewe performance & 0.5 & 299 & 34.0 \\
1c Increase liveweight gain & 0.5 & & 35.3 \\
\hline 2. Aggressive model & & 321 & 32.8 \\
2a. Increase ewe numbers & 0.6 & 320 & \\
2c. Increase liveweight gain & 0.6 & & \\
\hline
\end{tabular}

Table 3 Comparison of the number and weight of sheep sold for various lime-application/oversowing models and pasture utilisation scenarios.

\begin{tabular}{lccc}
\hline Model + Scenario & $\begin{array}{l}\text { Ewes } \\
\text { Works }\end{array}$ & $\begin{array}{c}\text { Ewe hoggets } \\
\text { Store }\end{array}$ & \multicolumn{2}{c}{ Mixed Hoggets } \\
\hline Base model & & & \\
-Number & 613 & 332 & 2324 \\
- Weight $(\mathrm{kg})$ & 18.2 & 30.0 & 33.1 \\
\hline
\end{tabular}

\section{Conservative model}

1a. Increase ewe numbers (Yr3)

$\begin{array}{lccc}\text { - Number } & 638 & 346 & 2416 \\ \text { - Weight }(\mathrm{kg}) & 18.3 & 30.0 & 33.1\end{array}$

1b. Increase ewe performance

$\begin{array}{lrrr}\text { - Number } & 613 & 332 & 2705 \\ \text { - Weight }(\mathrm{kg}) & 18.2 & 30.5 & 33.0\end{array}$

1c. Increase liveweight gain

$\begin{array}{lccc}\text { - Number } & 613 & 332 & 2323 \\ \text { - Weight }(\mathrm{kg}) & 18.2 & 34.8 & 37.2\end{array}$

\section{Aggressive model}

2a. Increase ewe numbers ( $\mathrm{Yr} 3$ )

- Number

- Weight (kg)

2c. Increase liveweight gain

$$
\text { - Number }
$$

- Weight (kg)
699

18.3

613

18.9
377

30.0

332

40.5
2416

2705

33.0

2323

37.2

\section{Sources of income}

Sources of revenue for the various scenarios were net sheep sales, wool and beef sales (Table 4). For net sheep sales, Scenario 1a (year 3) and Scenarios 1b and 1c all had higher sales $(\$ 375,510, \$ 408,090$ and $\$ 401,910$ respectively) compared to the base model of $\$ 361,300$. However, increasing ewe numbers took three years to reach the lower level of net sheep income than the other two scenarios. The trend was similar in the aggressive model, with Scenarios 2a (year 3) and 2c reaching similar levels of net sheep sales of $\$ 412,050$ and $\$ 410,040$ respectively. However, as with Scenario 1a, Scenario 2a took three years to reach that level of stock sales.

Revenue from wool increased for both Scenarios 1a and 2 a compared to the base model, as the number of 
Table 4 Comparison of sources of income for various lime-application/oversowing models and pasture utilisation scenarios.

\begin{tabular}{|c|c|c|c|c|}
\hline & \multicolumn{2}{|c|}{ Sheep } & \multirow{2}{*}{$\frac{\text { Wool }}{(\$)}$} & \multirow{2}{*}{$\begin{array}{c}\text { Beef } \\
(\$)\end{array}$} \\
\hline & $\begin{array}{l}\text { Net sales } \\
\text { (\$) }\end{array}$ & $\begin{array}{l}\text { Capital livestock } \\
\text { value change (\$) }\end{array}$ & & \\
\hline Base model & 361,300 & 0 & 209,900 & 131,000 \\
\hline \multicolumn{5}{|l|}{ 1. Conservative model } \\
\hline \multicolumn{5}{|l|}{ 1a. Increase ewe numbers } \\
\hline - Year 1 & 367,890 & $-23,090$ & 209,760 & 115,370 \\
\hline - Year 2 & 271,530 & 54,820 & 213,150 & 126,990 \\
\hline - Year 3 & 375,510 & & 218,400 & 130,940 \\
\hline 1b. Increase ewe performance & 408,090 & 0 & 209,330 & 130,990 \\
\hline 1c. Increase liveweight gain & 401,910 & 0 & 209,100 & 130,990 \\
\hline \multicolumn{5}{|l|}{ 2. Aggressive model } \\
\hline \multicolumn{5}{|l|}{ 2a. Increase ewe numbers } \\
\hline - Year 1 & 363,860 & $-11,590$ & 209,760 & 115,370 \\
\hline - Year 2 & 265,910 & 66,880 & 217,970 & 127,940 \\
\hline - Year 3 & 412,050 & 0 & 239,220 & 130,940 \\
\hline 2c. Increase liveweight gain & 410,040 & 0 & 206,950 & 136,950 \\
\hline
\end{tabular}

sheep increased in years 2 and 3 (Table 3). Income from wool was driven by sheep shorn and was similar across the remaining scenarios.

Beef income was lower that the base model for years 1 and 2 for both Scenarios 1a and 2a (Table 3), as feed was directed to building ewe numbers. Scenario $2 \mathrm{c}$ was the only instance where there was sufficient total daily dry-matter intake to increase both sheep and cattle liveweight gain. Thus the beef income was higher (5\%) than the base model.

\section{Financial results}

Scenario 2a produced the highest level of profitably with an EBITR 24\% higher than the base model (Table 5). However, it took two years to build the maternal ewe flock to the desired size and this financial result is from year 3. Once the EBITR is adjusted to a present value that can be compared to the other scenarios, this option is less attractive in the short term.

Scenario $1 \mathrm{~b}$ achieved an EBITR of $\$ 41,290$, which was $17 \%$ higher than the base model compared with an EBITR of $\$ 34,600$ for Scenario 1c, which was 14\% higher than the base model. Both Scenarios 1c and 2c produced similar levels of profitability with EBITRs of $\$ 284,690$ and $\$ 283,400$ respectively but Scenario $1 \mathrm{c}$ resulted in a lower revenue $(\$ 741,950)$ (but also proportionally lower total farm expenses) to generate a similar EBITR to Scenario 2c. The expenses were calculated primarily on a 'per stock unit' basis, where a stock unit was considered to be $550 \mathrm{~kg}$ DM eaten. Thus subtle changes in costs due to additional production were captured.

\section{Discussion}

Modelling across an entire simulated farm demonstrated that improvements in productivity and profitability were possible though land improvement by lime-application/ oversowing to varying extents. Increasing ewe numbers across $2.8 \%$ of the farm (Scenario $2 \mathrm{a}$ ) resulted in the highest level of profitability of all the scenarios tested and was the most attractive financial option over the long term for the final farm system. However, the cost of building capital stock can be expensive in terms of both time and money, requiring two years of reduced income and profit to reach the final farm system. Therefore, other scenarios became financially more attractive in the short term when the cost of building capital stock was included, and increasing ewe numbers over $2.8 \%$ of the farm was discounted back to a present value for comparison.

Gains were modest given that they arose from developing small areas of the farm and then measuring changes in productivity and profitability at the wholefarm scale.

Increasing ewe performance over $0.6 \%$ of the farm area would take several years to achieve the desired gains in productivity (Stevens \& Young 2013) so, as with increasing ewe numbers over the same area, this is not a short-term option. Increasing liveweight gain requires no increase in maternal ewe flock size 
Table 5 Comparison of financial results for various lime-application/oversowing models and pasture utilisation scenarios.

\begin{tabular}{|c|c|c|c|c|c|}
\hline & $\begin{array}{l}\text { Revenue } \\
\text { (\$) }\end{array}$ & $\begin{array}{l}\text { Total farm expenses } \\
\text { (\$) }\end{array}$ & $\begin{array}{c}\text { EBITR } \\
\text { (\$) }\end{array}$ & $\begin{array}{l}\text { Increase over } \\
\text { base model }\end{array}$ & $\begin{array}{c}\% \\
\text { change }\end{array}$ \\
\hline Base model & 702,150 & 452,060 & 250,090 & & \\
\hline \multicolumn{6}{|l|}{ 1. Conservative model } \\
\hline \multicolumn{6}{|l|}{ 1a. Increase ewe numbers } \\
\hline -At year 3 & 725,000 & 458,080 & 266,920 & 16,830 & 7 \\
\hline -Comparable present value & 633,240 & 400,100 & 233,140 & $-16,950$ & -7 \\
\hline 1b. Increase ewe performance & 748,360 & 456,980 & 291,380 & 41,290 & 17 \\
\hline 1c. Increase liveweight gain & 741,950 & 457,260 & 284,690 & 34,600 & 14 \\
\hline \multicolumn{6}{|l|}{ 2. Aggressive model } \\
\hline \multicolumn{6}{|l|}{ 2a. Increase ewe numbers } \\
\hline -At year 3 & 782,210 & 473,250 & 308,960 & 58,870 & 24 \\
\hline - Comparable present value & 683,210 & 413,350 & 269,860 & 19,770 & 8 \\
\hline 2c. Increase liveweight gain & 753,940 & 470,540 & 283,400 & 33,310 & 13 \\
\hline
\end{tabular}

or lambing percentage but it would still take time to achieve the budgeted gains in liveweight.

New Zealand high country is known for extremes in climate (Morris 2009). Bad weather during the initial stages of any development could adversely affect the survival and growth of the new pastures. There is also a high level of uncertainty around what level of productivity is possible and within what time frame. Increasing ewe numbers is the most explicit of the changes required and so easier to include in the model than other factors. Although all modelled scenarios require time to develop, obtaining estimates from the whole-farm simulation is a first step to investigating the potential returns and practicality and sustainability of a land-development programme.

Other key aspects of farm development are infrastructure and labour. The suitability of infrastructure, yards, woolshed and, in particular, fencing would have a large influence on whether any development is practical and realistic for a high-country property. Farms with spare capacity in their woolshed and yards, could increase ewe numbers or performance scenarios, whereas those without additional capacity maybe restricted to the increase liveweight gain scenario. Fencing, which is critical for subdivision and so pasture utilisation (Chapman \& Macfarlane 1985), can be expensive. Non-electric conventional fencing cost $\$ 24.88$ per metre on steep country, $\$ 17.88$ on rolling country and $\$ 16.36$ on flat terrain (Agribusiness Group 2016). Staff and labour costs were included in the model on a 'per stock unit' basis allowing for gradual changes in expenditure in line with changes in livestock numbers. As with the infrastructure costs, changes in the farm system may generate a threshold above which another staff member needs to be hired, the costs of which may not be adequately covered in the labour costs per stock unit. In short, this development maybe attractive to farmers with spare capacity in their existing infrastructure and staff/labour, and unattractive to those who do not.

The livestock or product prices represent a financial risk. The prices for products in 2019 were high (StatsNZ 2019), and future research could run selected models and scenarios with a wider range of product prices, to undertake a sensitivity analysis.

The environmental impact of intensification involving capital lime applications to develop targeted areas of the high country is another key consideration for future research. This could be investigated by analysing the scenarios with different software.

This study has taken the first step into quantifying potential production and profitability benefits of highcountry farm development via lime, superphosphate and clover application at a whole-farm scale. The results from this study suggest that there is potential for varying gains in productivity and modest profitability gains between 14 and $17 \%$ if ewe numbers are not altered in the short term from the targeted landimprovement strategies. However, these findings are based heavily on a base model under ideal conditions.

\section{Conclusions/Practical implications/Relevance}

There is potential for modest gains in productivity and profitably by improving land with lime, superphosphate and clover. The key risks to the production and economic impacts are climatic, the productive capacity of the land and the existing amount and suitability of existing farm infrastructure. 
These results indicate modelling capital inputs of lime and legumes for interested high country farming businesses may be worthwhile. Discussions and experience could then focus on how the development policy will perform in that environment, e.g. rainfall, with a range of financial conditions e.g. product prices and the farming infrastructure and system used by that business.

\section{ACKNOWLEDGEMENTS}

A special thanks to Farmax for the use of Farmax Professional for the purpose of this project. Also, thanks to Brian Speirs and Jane Chrystal from Beef + Lamb New Zealand for enabling me access to SI high country quintile analyses data.

\section{REFERENCES}

Agribusiness Group 2016. Ministry for Primary Industries stock exclusion costs report [Technical Paper No: 2017/11]. Ministry for Primary Industries, Wellington, New Zealand. 29 p. https://www.mpi. govt.nz/dmsdocument/16537/direct

Beef + Lamb New Zealand. 2019. Sheep and beef farm survey: Class 1 S.I. High Country - New Zealand. Retrieved 30 March 2019 from: https://beeflambnz. com/data-tools/sheep-beef-farm-survey

Chapman DF, Macfarlane MJ. 1985. Pasture growth limitations in hill country and choice of species. Grassland Research and Practice Series 3: 25-29.

Farmax. n.d. About Farmax. Retrieved 4 May from: http://www.farmax.co.nz/about.

Frengley G, Anderson C. 1989. Pragmatism in hill pasture renovation. Proceedings of the New Zealand Grassland Association 50: 151-156. https://doi. org/10.33584/jnzg.1989.50.1875

Gaukrodger L. 2015. Intensification of east coast hill country farming. Kellogg Rural Leadership Programme, Christchurch, New Zealand. 36p. https:// ruralleaders.co.nz/the-next-step-intensification-ofeast-coast-hill-country-farming-lynda-gaukrodger/

Haynes R, Williams P. 1993 Nutrient cycling and soil fertility in the grazed pasture ecosystem. Advances in Agronomy 49: 119-199. https://doi.org/10.1016/ S0065-2113(08)60794-4

Hofmann RW, Lin W, Stilwell SA, Lucas RJ. 2007. Comparison of drought resistance in strawberry clover and white clover. Proceedings of the New Zealand Grassland Association 69: 219-222. https:// doi.org/10.33584/jnzg.2007.69.2658

Maxwell TMR, Moir JL, Edwards GR. 2010. Influence of environmental factors on the abundance of naturalised annual clovers in the South Island hill and high country. Proceedings of the New Zealand Grassland Association 72: 165-170. https://doi. org/10.33584/jnzg.2010.72.2807
Moir JL, Moot DJ. 2010 Soil pH, exchangeable aluminium and Lucerne yield responses to lime in a South Island high country soil. Proceedings of the New Zealand Grassland Association 80: 191-196. https://doi.org/10.33584/jnzg.2010.72.2788

Moir JL, Moot DJ. 2014 Medium-term soil pH and exchangeable aluminium response to liming at three high country locations. Proceedings of the New Zealand Grassland Association 76: 41-46. https:// doi.org/10.33584/jnzg.2014.76.2963

Moir JL, Jordan P, Moot DJ, Lucas R. 2016 Phosphorus response and optimum $\mathrm{pH}$ ranges of twelve pasture legumes grown in an acid upland New Zealand soil. Journal of Soil Science and Plant Nutrition. 16: 438-460. https://doi.org/10.4067/S071895162016005000038

Morris ST. 2009. Economics of sheep production. Small Ruminant Research 86: 59-62. https://doi. org/10.1016/j.smallrumres.2009.09.019

Shadbolt N, Gardner J. (2005). Financial Management. In: Shadbolt N \& Martin N. Eds. Farm Management in New Zealand. South Melbourne, Australia: Oxford University Press.

StatsNZ. 2019. Lamb export prices spring to a new high. Retrieved 18 May from: https://www.stats.govt. nz/news/lamb-export-prices-spring-to-a-new-high

Stevens DR, Young G. 2013. Using data from large scale farming operations to understand the importance of feeding the ewe to improve whole farm performance. Proceedings of the New Zealand Grassland Association 75: 97-102. https://doi. org/10.33584/jnzg.2013.75.2929

\section{APPENDIX}

Farm expenses for the base lime-application/ oversowing model

\begin{tabular}{lc}
\hline & Farm Expenses for the Base model (\$/SU) \\
\hline Wages & 7.6 \\
Management wage & 0.3 \\
Animal health & 3.3 \\
Shearing & 2.9 \\
Feed conservation & 11.0 \\
Purchased feeds & 3.7 \\
Fertiliser (excl. N \& lime) & 7.0 \\
Lime & 0.6 \\
Weed and pest & 2.4 \\
Vehicle expenses & 6.6 \\
Fuel & 5.1 \\
Repairs and maintenance & 3.4 \\
Freight and cartage & 1.5 \\
Electricity & 0.6 \\
Administration expenses & 1.8 \\
Insurance & 3.1 \\
ACC levies & 1.2 \\
Rates & 2.0 \\
Depreciation & 4.3 \\
\hline
\end{tabular}

